\title{
APLIKASI MEMBRAN KERAMIK BUATAN DENGAN PRETREATMENT PADA PENJERNIHAN AIR SUNGAI MUSI
}

\author{
Husnah \\ Dosen PNSD dpk Program Studi Teknik Kimia \\ Universitas PGRI palembang \\ e-mail : husnahpgri@gmail.com
}

\begin{abstract}
ABSTRAK
Membran merupakan salah satu alternatif dalam pengolahan berbagai sumber air terutama untuk air permukaan. Salah satu membran yang umum digunakan adalah membran keramik. Membran keramik dalam penelitian ini merupakan hasil buatan dengan bahan dasar tanah liat. Membran ini digunakan dalam penjernihan air Sungai Musi dengan pretreatment awal menggunakan pasir silika dan karbon aktif. Proses Pengolahan ini bertujuan untuk memperbaiki kualitas air Sungai Musi tersebut. Proses filtrasi dilakukan dengan tekanan 36 psi. Waktu pengambilan permeate dilakukan pada 15, 30, 45 dan 60 menit. Parameter yang diamati pada proses filtrasi ini adalah Fluks, pH, kekeruhan, TDS.
\end{abstract}

Kata kunci : Membran Keramik Buatan, Pretreatment, Pasir Silika, Karbon aktif, Filtrasi..

\section{PENDAHULUAN}

Sungai Musi adalah sebuah sungai yang terletak di Provinsi Sumatera Selatan, Indonesia dengan panjang sungai sekitar $750 \mathrm{~km}$ dan merupakan sungai yang terpanjang di Pulau Sumatera. Sejak masa keemasan Kerajaan Sriwijaya, sungai Musi ini terkenal sebagai sarana utama transportasi kerajaan dan masyarakat. Ini tetap berlanjut pada masa pemerintahan kesultanan Palembang Darussalam.

Hingga kini pun sungai Musi masih menjadi alternatif jalur transportasi ke daerah tertentu dan untuk kepentingan tertentu. Setiap hari banyak kapal baik kapal barang maupun kapal angkutan manusia yang hilir mudik melintas di sini. Letaknya yang strategis membuat beberapa perusahaan menempatkan pabriknya di tepian sungai ini. PT. Pusri, PT. Pertamina dan PT. Semen Baturaja adalah contoh dari beberapa industri yang ada di sepanjang aliran sungai Musi yang juga memanfaatkan keberadaan sungai Musi ini.

Banyak masyarakat sekitar memanfaatkan sungai Musi untuk keperluan sehari-hari. Misalnya memasak, mencuci, mandi, bahkan buang air besar dan kecil pun disungai ini. Dan perusahaan daerah air minum (PDAM) juga memanfaatkan air dari sungai Musi ini sebagai bahan baku untuk memenuhi kebutuhan air bersih bagi masyarakat.

Pemanfaatan lain dari sungai Musi ini adalah sebagai tempat wisata. Di tepi Sungai Musi dapat dinikmati kemegahan Palembang tempo dulu. Banyak bangunan bersejarah terletak di sini. Salah satunya adalah Benteng Kuto Besak, Museum Sultan Mahmud Baddarudin II, dan Jembatan Ampera, atau bisa juga berkeliling sungai Musi dengan naik ketek (perahu kecil yang suara mesinnya berisik) untuk melihat kehidupan masyarakat disekitar Sungai Musi. 


\section{TINJAUAN PUSTAKA}

Anak Sungai Musi merupakan sumber bahan baku air untuk warga Sumsel, sehingga kelayakannya harus sesuai standar baku. Menurut budayawan Palembang, Djohan Hanafiah, di masa pemerintahan kolonial Belanda semasa 1930-an, jumlah anak Sungai Musi di Palembang mencapai 316 buah. Namun, kini jumlah tersebut menyusut tajam. Hanya tinggal puluhan anak sungai dengan sebagian besar kondisi yang memprihatinkan.

Sungai yang membelah kota Palembang itu ternyata tercemar limbah yang didominasi limbah rumah tangga, dan sisanya limbah industri. Data yang disampaikan Kepala Badan Lingkungan Hidup (BLH) Sumsel menyebutkan, sekitar 70 persen air Sungai Musi tercemar limbah rumah tangga, sedangkan sisanya 30 persen tercemar limbah perusahaan atau industri.

Beberapa anak sungai di Kota Palembang berisiko tercemar tersebut di antaranya, yaitu Sungai Bendung, Sungai Aur, Sungai Sekanak, Sungai Buah, Sungai Ogan, Sungai Demang Jambul, Sungai Sintren, Sungai Jeurju, dan Sungai Rendang. Selain menimbulkan bau tidak sedap, sampah mengambang di aliran anak sungai ini. Sampah plastik, kayu, daun-daun, dan lainnya hanyut mengikuti aliran menuju Sungai Musi. Meskipun warna airnya hitam pekat masih sering digunakan sebagian warga terutama anak-anak untuk mandi.

Tingkat pencemaran di Sungai Musi meningkat akibat aktivitas industri dan limbah rumah tangga. Unsur pencemar tertinggi, seperti fenol, besi, dan fosfat, sudah melebihi nilai ambang batas sehingga berpotensi mengancam organisme sungai. Sebagian besar limbah rumah tangga tersebut masuk Sungai Musi melalui aliran anak sungainya yang bermuara ke Sungai Musi. Karena air merupakan larutan yang hampir sangat universal, maka zat-zat yang paling alamiah maupun buatan hingga tingkat tertentu terlarut di dalamnya. Pencemaran air adalah peristiwa masuknya atau dimasukannya makhluk hidup, zat, energi, dan atau komponen lainnya kedalam air oleh kegiatan manusia, sehingga kualitas air turun sampai pada tingkat tertentu yang menyebabkan air tidak dapat berfungsi lagi sesuai peruntukannya ( Peraturan Gubernur Sumsel No.18 thn 2005 ) . Kualitas air yang terganggu ditandai dengan perubahan bau, rasa, dan warna. Pencemaran air meliputi pencemaran di perairan darat, seperti danau dan sungai, serta perairan laut.

Agar air permukaan dapat dipergunakan sebagai sumber air bersih perlu dicari teknologi pengolahan air yang sesuai. Salah satu teknologi pengolahan air yang telah menjadi topik hangat dalam beberapa tahun terakhir ini adalah teknologi membran. Pemisahan dengan membran memiliki banyak keunggulan diantaranya pemisahan dengan membran tidak membutuhkan zat kimia tambahan dan juga kebutuhan energinya sangat minimum. Membran dapat bertindak sebagai filter yang sangat spesifik. Hanya molekul-molekul dengan ukuran tertentu saja yang bisa melewati membran sedangkan sisanya akan tertahan di permukaan membran. Selain keunggulan-keunggulan yang telah disebutkan, teknologi membran ini semakin canggih, efisien, efektif, selektif, biaya kapital, operasi dan pemeliharaan sistem terus makin ditekan, murah, kompetitif dibanding cara-cara tradisional konvensional yang setara (Hartono, 1997).

\section{METODOLOGI PENELITIAN}

Pada percobaan ini filter keramik yang digunakan yaitu filter keramik buatan. Tahapan-tahapan penelitian yang dilakukan antara lain ; tahap awal penelitian dengan proses pembuatan membran. Tahap kedua adalah melakukan pengujian sampel awal dilanjutkan running alat dan tahap terakhir menguji sampel akhir . Hasil dari penelitian ini akan ditampilkan dalam bentuk tabel dan grafik. 
Adapun lokasi-lokasi yang digunakan sebagai tempat penelitian ini adalah : Lokasi pengambilan sampel air baku bertempat di Sungai Musi. Penelitian ini adalah skala laboratorium yang dilaksanakan di laboratorium Teknik Pemisahan Jurusan Teknik Kimia Fakultas Teknik Universitas Sriwijaya. Analisa sampel untuk parameter limbah cair awal dan akhir dilakukan di

\section{Skema Peralatan}

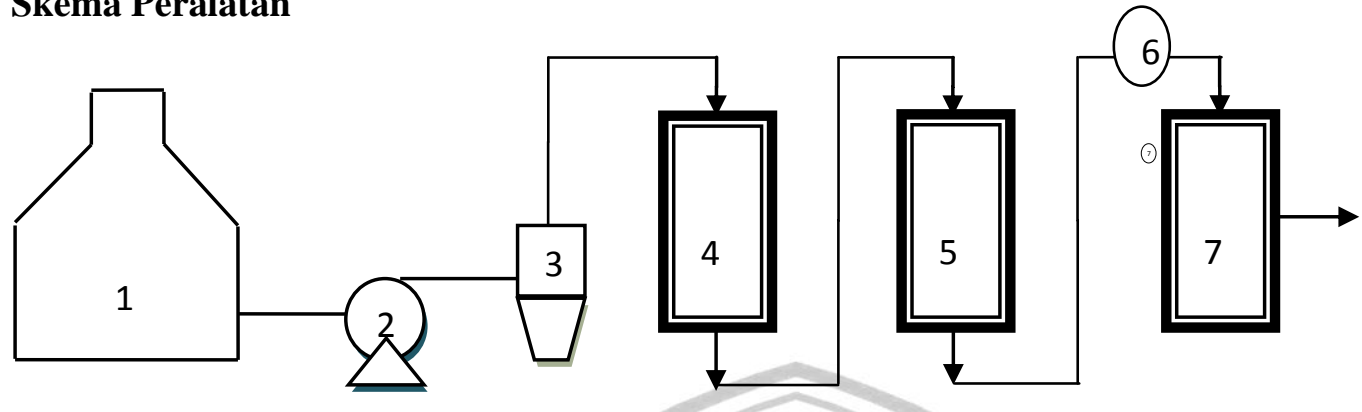

Gambar 1 : Rangkaian Alat Penelitian Non Koagulan

Keterangan: 1. Tangki Air, 2. Pompa, 3. Flowmeter umpan 4. pasir silika 5. karbon aktiv 6. Pressure Gauge 7. Filter Keramik

Pengambilan data dari sampel permeate dilakukan setiap 15, 30, 45 dan 60 menit. Parameter yang dianalisa meliputi fluks, $\mathrm{pH}$, kekeruhan dan TDS.

\section{PEMBAHASAN}

Pengaruh pretreatment terhadap Fluks :

Salah satu parameter untuk melihat kinerja dari membran adalah fluks yang merupakan ukuran kecepatan suatu spesi melewati membran persatuan luas dan waktu dengan gradient tekanan sebagai gaya dorong. Fluks umunya dirumuskan sebagai berikut :

$$
\mathrm{JV}=\frac{V}{A \cdot t}
$$

$$
\begin{aligned}
\mathrm{J} & =\text { Fluks } \\
\mathrm{V} & =\text { Volume permeat }(\mathrm{ml}) \\
\mathrm{A} & =\text { Luas permukaan membran }\left(\mathrm{cm}^{2}\right) \\
\mathrm{T} & =\text { Waktu }(\text { det })
\end{aligned}
$$

Laboratorium Kualitas Air, Badan Riset dan Standardisasi Nasional Provinsi Sumatera Selatan.

Alat dan bahan utama yang digunakan adalah : Filter keramik buatan, Flow meter, Selang plastik, Pressure gauge, Pipa PVC, Pompa, pH meter, TDS meter, Gelas ukur dan gelas erlenmeyer, AAS, Tabung reaksi, Kertas saring, Jar test, Oven, Timbangan elektrik, air Sungai Musi.

Pada penelitian ini volume permeat yang dihasilkan pada tekanan 36 psi dengan variasi waktu $(15,30,45$ dan 60 menit) diamati, sehingga nilai fluks dapat diketahui melalui perhitungan menggunakan per-samaan untuk fluks. Tabel dan grafik dibawah ini menggambarkan pengaruh pretreatment terhadap fluks. 
Tabel 1. Fluks permeate

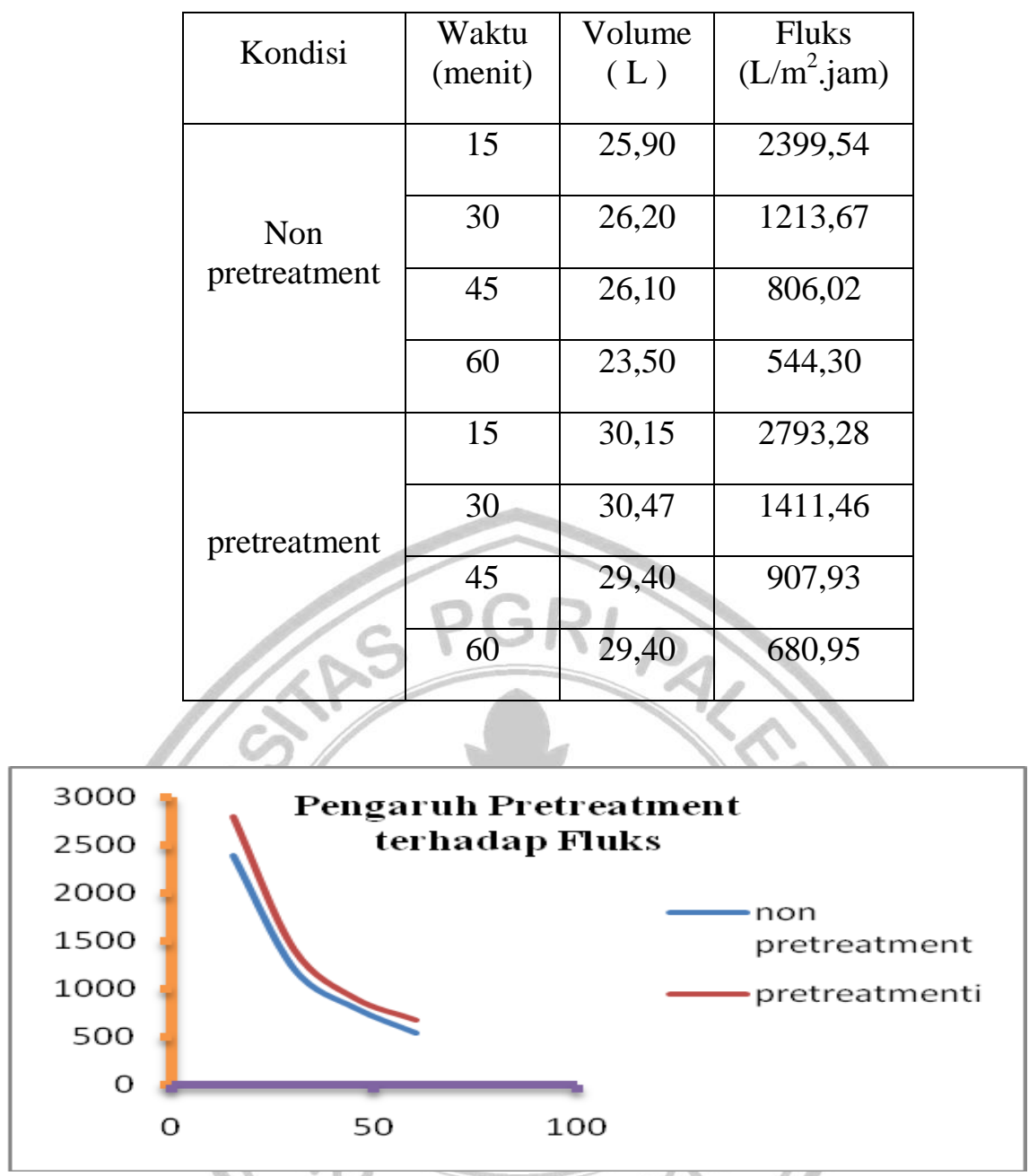

Gambar 2. Pengaruh pretreatment terhadap fluks

Dari grafik fluks di atas terlihat bahwa dengan adanya proses pretreatment dengan pasir silika dan karbon aktif nilai fluks permeate lebih besar dibandingkan fluks permete tanpa pretreatment. Secara umum mula-mula fluks meningkat tetapi lambat laun terjadi penurunan fluks yang berarti bahwa adanya penurunan kinerja membran. Hal ini bisa diakibatkan adanya fouling sepanjang proses operasi filtrasi air baku, diantaranya akibat pengendapan dari padatan yang mungkin masih terlarut dalam air baku dan lolos pada permukaan membran sehingga menutup sebagian pori-pori membran.

Analisa $p H$

$\mathrm{pH}$ merupakan salah satu ukuran yang menentukan kualitas air. Kualitas air yang baik adalah kadar dimana masih memungkinkan kehidupan biologis di dalam air berjalan dengan baik. $\mathrm{pH}$ yang baik bagi air minum dan air limbah adalah netral (pH 7) (Sugiharto, 1987). 
Tabel 2. $\mathrm{pH}$ permeate

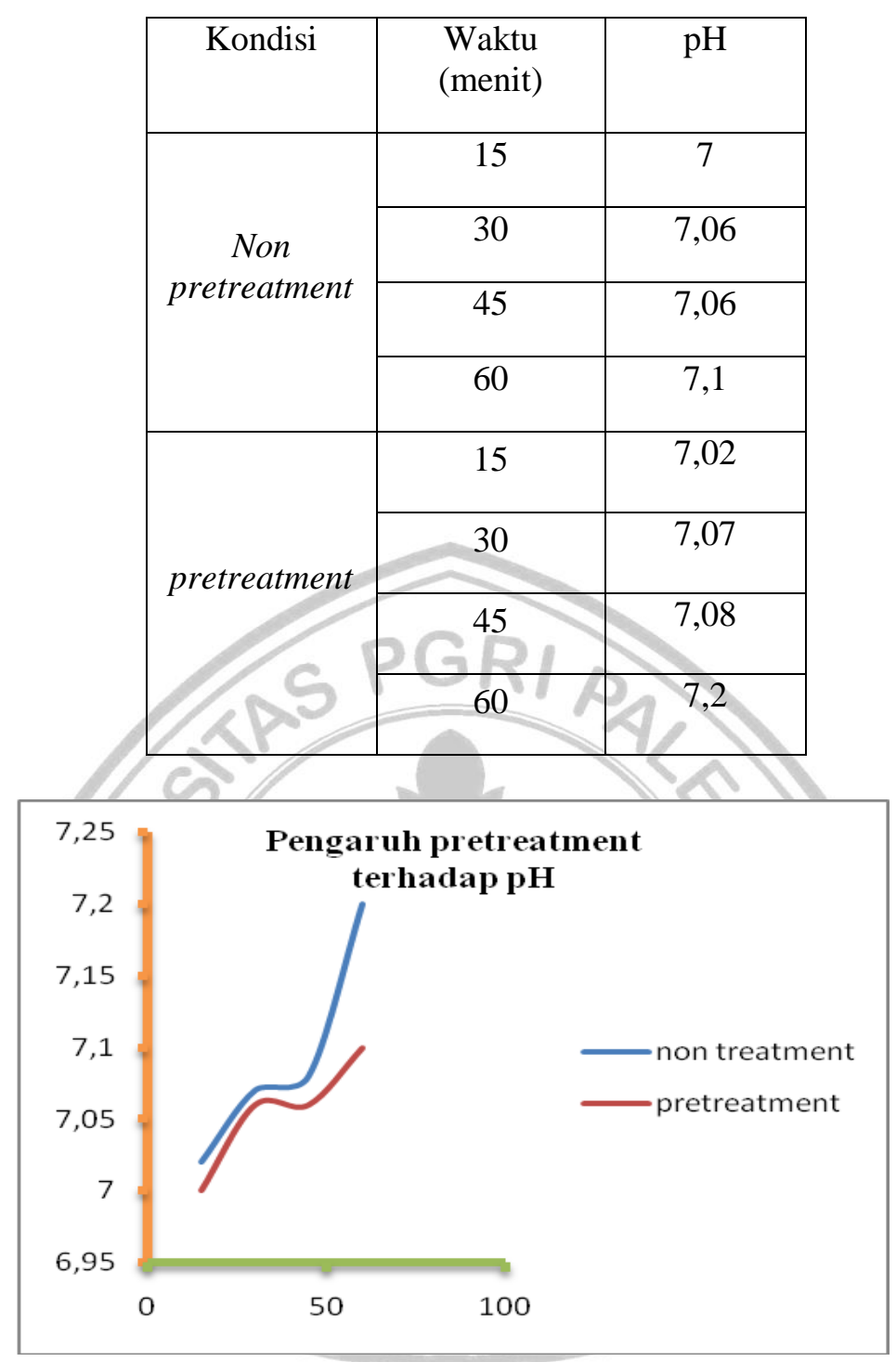

Gambar 3. Pengaruh pretreatment terhadap $\mathrm{pH}$

Terlihat dari grafik bahwa $\mathrm{pH}$ pada filtrasi tanpa pretreatment mengalami peningkatan $\mathrm{pH}$ seiring bertambahnya waktu. Sebaliknya pada filtrasi yang menggunakan pretreatment $\mathrm{pH}$ cenderung lebih stabil dikisaran 7.

Analisa Total Dissolve Solid (TDS)

TDS (Total Dissolve Solid) yaitu ukuran zat terlarut yang terdapat pada sebuah larutan. Ion-ion penyebab TDS digolongkan kedalam dua kelompok yaitu kelompok ion utama (sodium, kalsium, magnesium, bikarbonat, sulfat, dan klorida) dan ion sekunder (besi, strontium, kalium, karbonat, nitrat, flourida, boron dan silika) (Effendi, 2003). 
Pada filtrasi ini terjadi penurunan TDS cukup signifikan yaitu rata-rata sekitar $21 \%$ pada filtrasi tanpa pretreatment dan rata-rata $40 \%$ pada filtrasi melalui pretreatment. Berikut tabel dan grafik penurunan TDS :

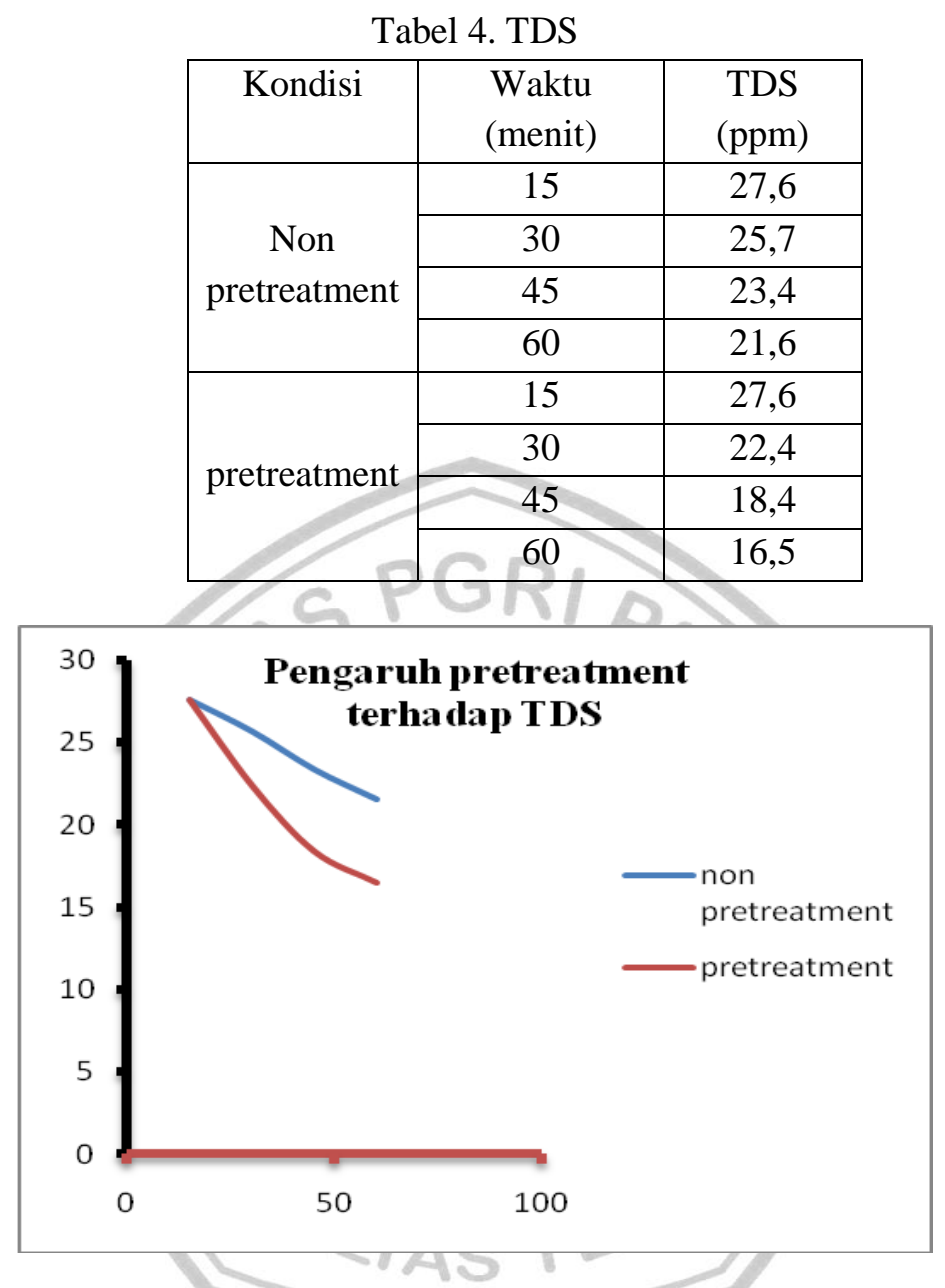

Gambar 4. Pengaruh pretreatment terhadap TDS

\section{Analisa Turbidity (Kekeruhan)}

Turbidity (Kekeruhan) merupakan salah satu syarat dalam pemakaian air baku untuk memenuhi kebutuhan air sehari-hari. Pada penelitian ini terjadi penurunan yang cukup signifikan dalam hal kekeruhan air, yaitu pada Filtrasi tanpa pretreatment terjadi penurunan $30 \%$, sedangkan pada filtrasi menggunakan pretreatment penurunan turbidity hingga mencapai $90 \%$. Hal ini terlihat pada tabel dan grafik dibawah ini : 
Tabel 5. Turbidity permeate

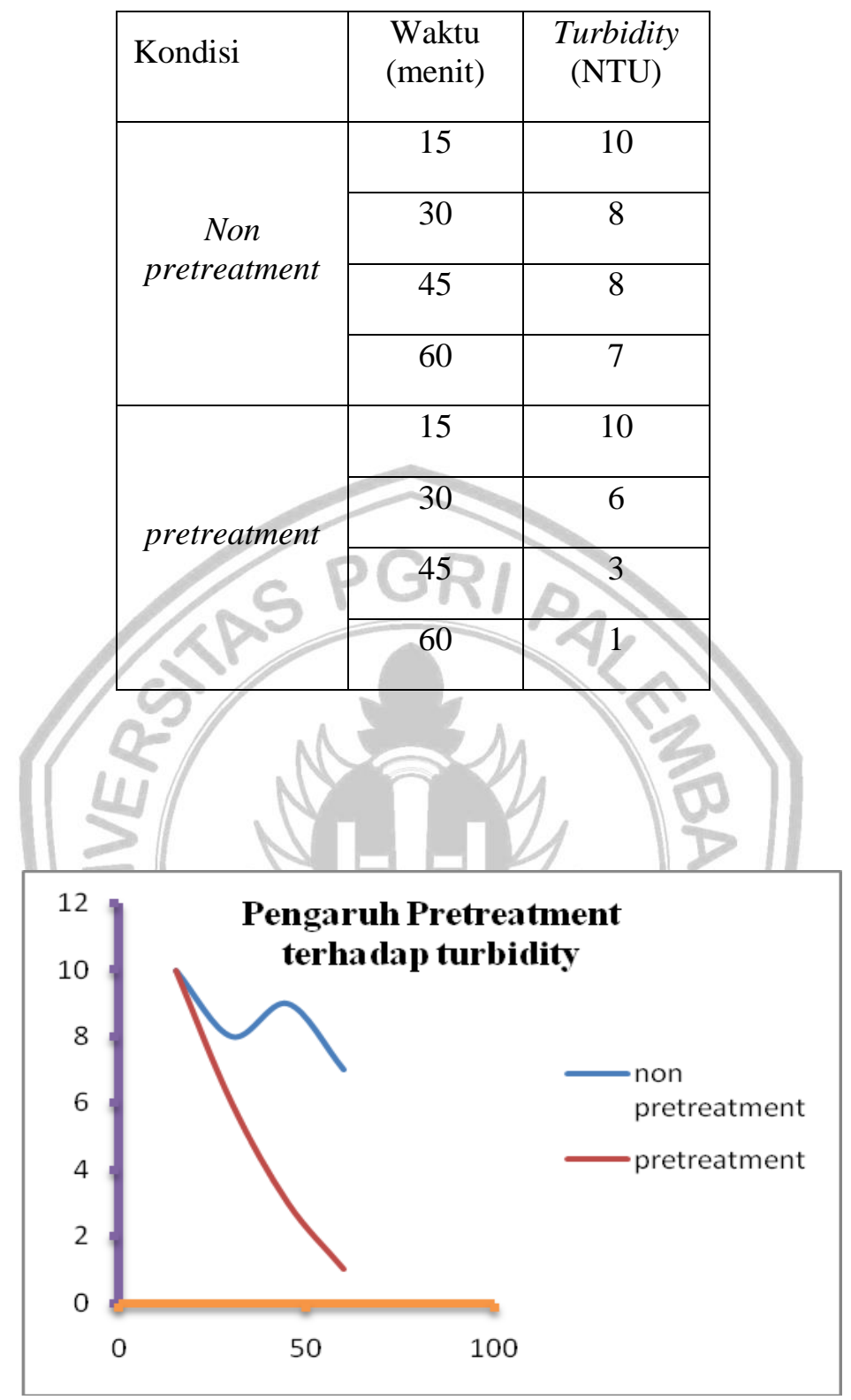

Gambar 5. Pengaruh pretreatment terhadap Turbidity

\section{KESIMPULAN}

1. Pretreatment yang dilakukan dengan melewatkan air baku melalui pasir silika dan karbon aktif mempengaruhi kinerja membran keramik.. Pada penelitian ini fluks lebih besar didapat pada filtrasi yang menggunakan pretraetment dibandingkan yang tidak memakai pretreatment .

2. Filtrasi dengan Membran Keramik dapat meningkatkan kualitas air Sungai Musi yang telah melewatinya terutama kekeruhannya dapat turun hingga $90 \%$. 


\section{DAFTAR PUSTAKA}

Hartono, A.J, (1997). Teknologi Membran Pemurnian Air. Edisi 1. Yogyakarta.

Sugiharto. (1987). Dasar-Dasar Pengelolaan Air Limbah. Jakarta. Universitas Indonesia Press

Effendi, Hefni. (2003). Telaah Kualitas Air bagi Pengelolaan Sumber Daya dan Lingkungan Perairan. Yogyakarta, Kanisius.

(2005). Peraturan Gubernur Sumatera Selatan No 18 tahun 2005 tentang Baku Mutu Limbah Cair (BMLC) bagi Kegiatan Industri, Hotel, Rumah Sakit, Domestik dan Pertambangan.

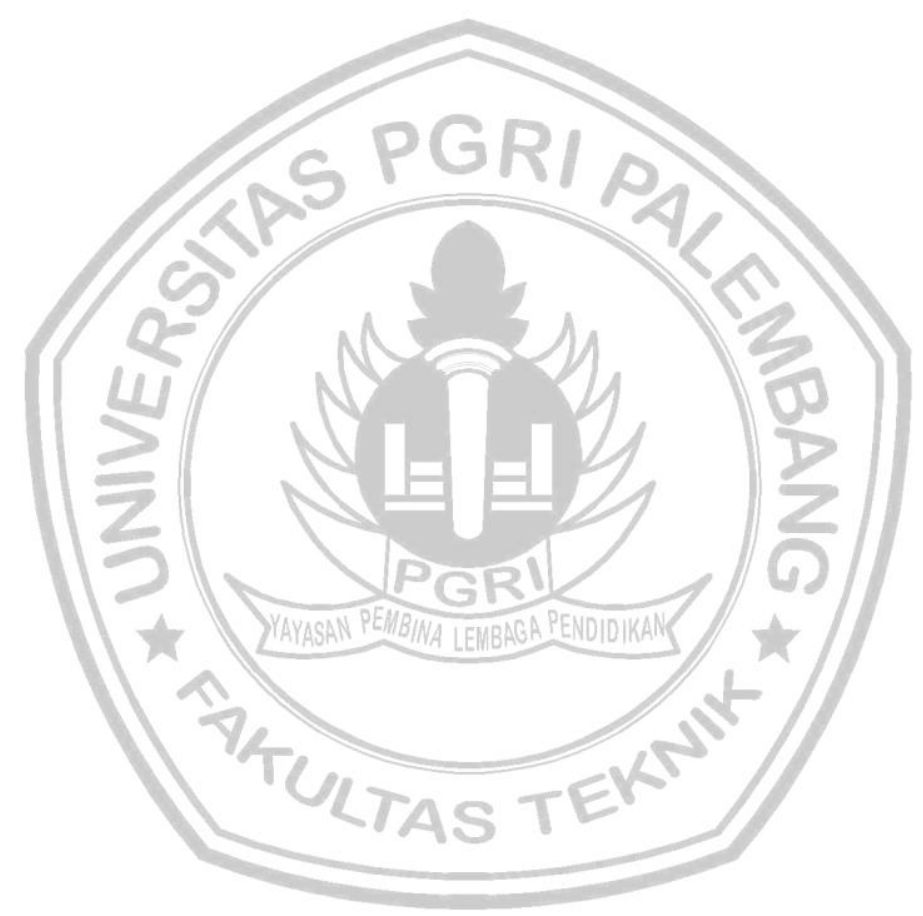

